Khazanah: Jurnal Studi Islam dan Humaniora

ISSN: 0215-837X (p); 2460-7606 (e), Vol. 19 (1), 2021, pp. 83-104

DOI: $10.18592 /$ khazanah.v19i1.4498

Submit: 20/02/2021 Review: 23/05/2021 Publish: 30/07/2021

\title{
FKUB DAN IMPLEMENTASI PENDIDIKAN AGAMA ISLAM MULTIKULTURAL DALAM MENGEMBANGKAN KERUKUNAN UMAT BERAGAMA PADA MASYARAKAT TENGGER
}

\section{Triana Rosalina Noor; Idrus; Mohamad Mujib Ridwan; Maskuri}

\author{
STAI An Najah Indonesia Mandiri, Sidoarjo; Universitas Nurul Jadid, Probolinggo; \\ Universitas Yudharta, Pasuruan; Universitas Islam Malang \\ trianasuprayoga@gmail.com; idrus@gmail.com; rmujib54@gmail.com ; \\ masykuri@unisma.ac.id
}

\begin{abstract}
This study aims to describe and analyze the spirit of tolerance values and the implementation of multicultural Islamic education in developing religious harmony in the Tengger Community. This study was conducted in the Tengger Muslim community, precisely in Sukapura and Krucil Village, Probolinggo. This study uses a qualitative approach with case study as a type, with data collection methods through interviens, observation and documentation. The informants of this study were members of the FKUB and tolerance activists in Probolinggo. The study found that the spirit of tolerance developed by FKUB and local religious leaders through Multicultural Islamic Education in order to develop religious harmony had a positive impact. The Tenggerese who live in Sukapura and Krucil villages were able to live side by side in peace. The values of tolerance were mutual respect, freedom of religion, acceptance of the existence of others and positive thinking. In the implementation process, the process of instilling a spirit of tolerance in the Muslim community is carried out through religious activities such as suroan, istighosah, public recitations, mauludan activities and tablil activities. In these activities, the value of tolerance was implied through the provision of understanding and knowledge regarding the importance of the spirit of tolerance (tolerance knowing), benceforth the Muslim community was able to feel the "feel" of the importance of tolerance in people's lives (tolerance feeling) and ultimately to live side by side. with other people in the society so that religious harmony was created (tolerance action).
\end{abstract}

Keywords: Spirit of Tolerance; Multicultural Islamic Education; Religious Harmony

\begin{abstract}
Abstrak: Penelitian ini bertujuan untuk mendeskripsikan dan menganalisis spirit nilai toleransi dan Implementasi Pendidikan Agama Islam Multikultural Dalam Mengembangkan Kerukunan Umat Beragama Pada Masyarakat Tengger. Penelitian ini dilakukan di masyarakat muslim Tengger tepatnya di Desa Sukapura dan Desa Krucil Kabupaten Probolinggo. Penelitian ini menggunakan pendekatan kualitatif dengan jenis studi kasus, dengan metode pengumpulan data melalui wawancara, observasi dan dokumentasi. Informan dari penelitian ini adalah jajaran FKUB yang merupakan salah satu penggiat toleransi di Kabupaten Probolinggo. Hasil penelitian ini adalah spirit toleransi yang dikembangkean FKUB dan tokoh agama setempat melalui Pendidikan Agama Islam Multikultural guna mengembangkan kerukunan umat beragama telah membawa dampake positif. Masyarakat Tengger yang tinggal di Desa Sukapura dan Desa Krucil mampu bidup berdampingan dengan damai. Nilai-nilai toleransi tersebut adalah saling menghormati, kebebasan beragama, menerima keberadaan orang lain dan berpikir positif. Pada proses implementasinya, proses penanaman spirit toleransi kepada masyarakat Muslim dilakukan
\end{abstract}


melalui kegiatan keagamaan seperti suroan, istighosah, pengajian umum, kegiatan mauludan dan kegiatan tablil. Pada kegiatan-kegiatan tersebut, nilai toleransi tersebut diimplikasikan melalui pemberian pemahaman dan pengetahuan terkait pentingnya spirit toleransi (tolerance knowing), untuk selanjutnya masyarakat muslim akan bisa merasakan "rasa" dari pentingnya toleransi dalam kehidupan masyarakat (tolerance feeling) dan pada akbirnya bisa bidup berdampingan dengan orang lain dalam masyarakat sebingga terciptalah kerukunan umat beragama (tolerance action).

Kata kunci: Spirit Toleransi; Pendidikan Agama Islam Multikultural; Kerukunan Umat Beragama

\section{Pendahuluan}

Fenomena intoleransi dan pelanggaran kebebasan beragama dan berkeyakinan cenderung meningkat di Indonesia, khususnya sejak tahun politik nasional tahun 2019 silam. Salah satunya adalah pada 1 September 2020 silam, telah terjadi pelarangan pembangunan fasilitas ibadah dan rumah dinas pendeta di Gereja Kristen Protestan Pakpak Dairi (GKPPD) Kecamatan Napagaluh, Kabupaten Aceh Singkil. Pelarangan ini membawa kecenderungan pada peningkatan ekspresi intoleransi dan diskriminasi terhadap kelompok-kelompok agama minoritas. ${ }^{1}$

Sebenarnya kasus-kasus intoleransi yang terjadi di Indonesia bukanlah satu atau dua kasus saja, melainkan masih marak terjadi dan pemerintah diminta untuk turun tangan dalam menyelesaikannya. Mengacu pada situs Komisi Nasional Hak Asasi Manusia Republik Indonesia (Komnas HAM RI), isu terkait perilaku intoleransi dan perampasan kebebasan berkeyakinan tergolong sepuluh besar aduan masyarakat per Januari 2021. ${ }^{2}$ Perilaku tersebut bisa berupa perobohan rumah ibadah, penutupan masjid, proses administrasi pembangunan tempat ibadah yang sulit atau juga perilaku penolakan masyarakat sekitar terkait agama atau etnis tertentu.

Perilaku yang mengarah kepada tindakan intoleransi yang terjadi sekarang ini, tidaklah terlepas dari karakteristik bangsa Indonesia yang memang tergolong menonjol dalam hal kemajemukan, baik secara vertikal maupun horizontal. Kemajemukan dalam sudut pandang horizontal bisa dilihat melalui agama, suku, bahasa, daerah dan budaya. Pada sudut pandang vertikal, kemajemukan vertikal berupa keragaman dalam pendidikan, status sosial ekonomi, mata pencaharian dan lainnya. ${ }^{3}$

Jika dilacak lebih jauh, faktor penyebab perilaku intoleransi di masyarakat antara daerah satu dengan yang lain sangatlah beragam. Adanya faktor-faktor eksternal seperti kondisi sosial politik negara dan faktor internal seperti ideologi telah

\footnotetext{
${ }^{1}$ Setara Institute, "Terjadi Penjalaran Intoleransi Di Daerah, Pemerintah Pusat Harus Hadir," 29 September 2020, n.d., https://setara-institute.org/terjadi-penjalaran-intoleransi-di-daerahpemerintah-pusat-harus-hadir/.

“"Data Aduan Komnas HAM RI,” n.d., http:// dataaduan.komnasham.go.id/\#/.

${ }^{3}$ Muhammad Tholchah Hasan, Pendidikan Multikultural Sebagai Opsi Penanggulangan Radikalisme (Malang: Lembaga Penerbitan Univ. Islam Malang, 2016), 33.
} 
membawa kepada pola-pola hidup masyarakat yang anti kebhinnekaan. ${ }^{4}$ Adanya gap ekonomi, kepentingan politik, hasrat kekuasaan atau adanya keinginan untuk menjadi unggul khususnya dalam jumlah pengikut agama seringkali menyebabkan konflik di masyarakat. ${ }^{5}$

Pada dasarnya, agama bukan sepenuhnya menjadi faktor pemicu konflik keagamaan atau tindakan intoleransi yang terjadi melainkan faktor non agama. Namun faktor "agama" acap kali dianggap sebagai pemicu perilaku intoleransi dan konflik yang terjadi di masyarakat. ${ }^{6}$ Masyarakat Indonesia menjadi mudah tergiring isu-isu kebencian yang menggiring pada prasangka beragama yang pada akhirnya membawa pada bentuk diskriminasi-diskriminasi yang terjadi dalam lingkungan masyarakat. ${ }^{7}$ Bahkan terdapat pula fenomena takfirisme yakni penyebarluasan paham agama yang literal dan kaku sehingga membawa pada pengembangan nilai-nilai yang intoleran bagi para jamaahnya. ${ }^{8}$ Artinya dibutuhkan peran dari pemerintah dan masyarakat untuk bisa meluruskan kondisi ketidaksepahaman yang ada agar keadilan sosial bisa tercipta dalam relasi sosial kemasyarakatan.

Pemerintah Republik Indonesia diberi amanah yang sangat besar oleh rakyat guna menghadapi kenyataan atas kebhinnekaan yang ada. Salah satu tugas yang diemban adalah dalam hal penataan umat beragama, sebagaimana UUD 1945 Pasal 29 ayat 2 yang menyatakan bahwa negara menjamin kemerdekaan semua warga negara untuk bebas memeluk agamanya dan beribadat menurut agama dan kepercayaan yang diyakininya tersebut.

Ada beberapa alasan yang melandasi pemerintah penting untuk mengatur kehidupan beragama diantaranya adalah kehidupan beragama memiliki keterkaitan historis dengan pemerintah, pemerintah penting untuk melakukan membuat regulasi terkait umat beragama dengan pemerintah dan dalam rangka terwujudnya kerukunan dan keamanan Nasional. ${ }^{9}$

Salah satu usaha pemerintah untuk menjaga kerukunan umat beragama dan menjaga keharmonisan hidup bermasyarakat, pemerintah membentuk sebuah forum yang bernama Forum Kerukunan Umat beragama (FKUB). FKUB merupakan lembaga yang didirikan guna menterjemahkan peran pemerintah dalam menjaga dan memelihara kerukunan Umat Beragama di Indonesia melalui Peraturan Bersama

\footnotetext{
4Triana Rosalina Noor, "Alternatif Pemecahan Masalah Pada Masyarakat Multikultural," $\mathrm{Al}$ Iman: Jurnal Keislaman Dan Kemasyarakatan 4, no. 2 (2020): 209.

${ }^{5}$ Ngainun Naim and Achmad Sauqi, Pendidikan Multikultural: Konsep Dan Aplikasi (Yogyakarta: Ar-Ruzz Media, 2017), 15.

${ }^{6}$ Triana Rosalina Noor, "Meneropong Indonesia: Sebuah Analisis Sosiologis Dan Psikologis Atas Konflik Benuansa Keagamaan Di Indonesia," Journal An-Nafs: Kajian Penelitian Psikologi 3, no. 2 (2018): 138, https://doi.org/10.33367/psi.v3i2.499.

${ }^{7}$ Triana Rosalina Noor, "Menepis Prasangka Dan Diskriminasi Dalam Perilaku Beragama Untuk Masa Depan Multikulturalisme Di Indonesia," Fikri: Jurnal Kajian Agama, Sosial Dan Budaya 5, no. 2 (2020): 220, https://doi.org/10.25217/jf.v5i2.1058.

${ }^{8} \mathrm{M}$ Khusnun Niam, "Peranan Majelis Taklim Áqo'idul Khomsin Pekalongan Terhadap Fenomena Takfirisme," Al-Adyan: Journal of Religious Studies 1, no. 1 (2020): 68.

${ }^{9}$ Hamzah Tualeka, Sosiologi Agama (Surabaya: IAIN Sunan Ampel Press, 2011), 164-65.
}

Khazanah, Vol. 19 (1), 2021 
Menteri Agama dan Menteri Dalam Negeri (PBM) No. 9 dan 8 Tahun 2006 tentang Pedoman Pelaksanaan Tugas Kepala Daerah/ Wakil Kepala Daerah dalam Pemeliharaan Kerukunan Umat Beragama, Pemberdayaan Forum Kerukunan Umat Beragama, dan Pendirian Rumah Ibadat di Indonesia. FKUB merupakan sebuah forum bentukan masyarakat yang digagas oleh pemerintah guna membangun, memelihara, dan memberdayakan umat beragama untuk kerukunan dan kesejahteraan (pasal 1 ayat 96) PBM No. 09 dan 08 tahun 2006). ${ }^{10}$

Tugas FKUB adalah menyelenggarakan dialog dengan tokoh agama dan tokoh masyarakat, sebagai penyalur aspirasi masyarakat terkait masalah sosial keagamaan yang pada nantinya akan digunakan oleh Bupati/ walikota sebagai pijakan pengambilan keputusan. Selain itu FKUB juga bertugas untuk menginformasikan ke masyarakat luas terkait peraturan perundang-undangan dan kebijakan di bidang keagamaan dalam konteks kerukunan umat beragama, serta sebagai pihak pemberi rekomendasi atas permohonan masyarakat terkait pendirian rumah ibadah (pasal 9 ayat (2) PBM Nomor 9 dan 8 Tahun 2006). FKUB memiliki peran strategis sebagai mediator, melakukan dialog dengan pemuka agama dan tokoh masyarakat, menampung dan menyalurkan aspirasi ormas keagamaan dan aspirasi masyarakat. ${ }^{11}$ Oleh karena FKUB keberadaannya sangat bermanfaat dalam tatanan masyarakat. Keberadaan FKUB diakomodir oleh pemerintah untuk ada di seluruh provinsi serta daerah di Indonesia termasuk diantaranya FKUB yang ada di Kabupaten Probolinggo.

FKUB Kab. Probolinggo memiliki fungsi sebagai rekanan pemerintah daerah dalam konteks membangun dan memelihara kerukunan umat beragama di masyarakat. Salah satunya adalah berperan serta aktif dalam penyelesaian konflik sosial yang terjadi di Desa Sukapura Kecamatan Sukapura dan Desa Krucil Kecamatan Krucil. Kedua desa tersebut merupakan desa yang dihuni oleh masyarakat Tengger yang terkenal dengan multi agama. Mengacu pada pengalaman lampau, pernah terjadi ketegangan di antara pemeluk agama yang membuat suasana kehidupan bermasyarakat menjadi kurang harmonis. Kejadian tersebut terkait adanya ketidaksepahaman warga dalam hal pendirian rumah ibadah umat Kristiani. Pendirian gereja tersebut dipermasalahkan oleh karena tidak memenuhi izin pendirian dan lokasinya pun bertempat di daerah yang mayoritas Muslim. Namun oleh karena adanya dukungan FKUB melalui kegiatan dan pembinaan yang dilakukan, dan juga peran serta pemerintah dan tokoh masyarakat setempat maka masalah tersebut dapat terselesaikan. Salah satu caranya adalah mediasi melalui tokoh-tokoh dan para pemuka agama. Salah satu cara yang dilakukan para pemuka agama Islam yang bernaung dalam FKUB adalah mengajak dan membawa masyarakat Muslim Tengger untuk

\footnotetext{
10“'Sosialisasi Peraturan Bersama Menteri Agama Dan Menteri Dalam Negeri Nomor 9 Tahun 2006 Dan Nomor 8 Tahun 2006," n.d., https:/ /www.kemendagri.go.id/.

${ }^{11}$ Achmad Munif and Ropingi Ropingi, "Peran Forum Kerukunan Umat Beragama (FKUB) Dalam Upaya Penangulangan Timbulnya Konflik Sosial Keagamaan Di Kota Kediri Tahun 2020," Realita: Jurnal Penelitian Dan Kebudayaan Islam 19, no. 1 (2021): 94, https://doi.org/DOI: https://doi.org/10.30762/realita.v19i1.3272.
} 
tetap menjaga kerukunan dan menjunjung toleransi. Para pemuka agama Islam mengembangkan kerukunan dalam beragama melalui penerapan nilai-nilai Pendidikan Agama Islam Multikultural. ${ }^{12}$

Pendidikan Agama Islam Multikultural dipahami sebagai sebuah kegiatan penting dalam konteks mentransformasikan nilai-nilai positif guna menyelesaikan sebuah permasalahan. Nilai-nilai Islam multikultural tersebut membawa pada pembentukan pribadi yang berakhlakul karimah dengan perubahan positif pada pola perilaku dan sikap yang multikultural di masyarakat. ${ }^{13}$ Salah satu nilai Pendidikan Agama Islam Multikultural yang penting untuk diterapkan dalam kehidupan sosial adalah nilai toleransi. ${ }^{14}$ Melalui spirit toleransi, FKUB Kabupaten Probolinggo bertekad untuk menjaga kerukunan umat beragama dan melalui spirit toleransi pulalah FKUB Kabupaten Probolinggo berusaha menanamkan nilai-nilai toleransi kepada masyarakat Tengger, khususnya masyarakat muslim agar memiliki kesadaran atas perbedaan yang ada di masyarakat agar konflik serupa tidak terjadi kembali.

Pendidikan Agama Islam Multikultural merupakan sebuah refleksi atas keharmonisan sebuah pemahaman atas persamaan dan perbedaan budaya. Hal ini penting guna memotivasi generasi penerus untuk tetap mempertahankan dan memperkuat wawasan budaya dan keunikan kebudayaan mereka sendiri. James A. Banks ${ }^{15}$ memberikan empat pendekatan dalam pendidikan multikultural yang pada prosesnya bisa diadopsi untuk Pendidikan Agama Islam Multikultural, yaitu: pertama, pendekatan kontributif. Pendekatan kontributif dilakukan melalui pelaksanaan proses seleksi atas buku-buku yang menjadi acuan aktivitas-aktivitas kemasyarakatan seperti aktivitas keagamaan dan kebudayaan. Melalui pendekatan ini diharapkan dalam meningkatkan pengetahuan terkait keragaman dalam sebuah kelompok sehingga dapat dikembangkan dengan cara memasukkan nilai-nilai unik dari berbagai varian pendidikan multikultural.

Kedua, pendekatan aditif. Pendekatan ini dilakukan melalui memberikan tambahan-tambahan atas muatan-muatan, tema-tema dan beragam sudut pandang ke dalam suatu perencanaan dalam pembelajaran tanpa mengubah struktur dasarnya. Maksudnya adalah melalui memasukkan nilai-nilai sebuah kelompok itu sendiri untuk dimasukkan dalam pembelajaran. Misalnya memasukkan nilai saling menghargai, saling menghormati dan lain sebagainya sebagai bahan ajar.

Ketiga, pendekatan transformatif. Pendekatan ini pada pelaksanaannya dilakukan melalui mengembangkan suatu konsep baru dengan proses perbandingan untuk selanjutnya dilakukan pemahaman baru yang dilihat dari berbagai sudut pandang. Penerapan pendekatan transformatif mengimplikasikan suatu konsep baru

\footnotetext{
${ }^{12}$ “Idrus, Wawancara, Probolinggo 29 Juli 2020."

${ }^{13}$ Fita Mustafida, Pendidikan Islam Multikultural: Konsep Dan Implementasi Proses Pembelajaran PAI Berbasis Nilai-Nilai Multikultural (Jakarta: PT. RajaGrafindo Persada, 2020), 8.

${ }^{14}$ Imam Safi'i, Multikulturalisme Beragama Di Masyarakat (Kajian Pendidikan Islam, Hindu Dan Kristen) (Malang: CV. Madza Media, 2020), 101.

${ }^{15}$ James A Banks and Cherry A McGee Banks, Multicultural Education: Issues And Perpectives 9th Edition (USA: John Wiley and Sons, Inc, 2016), 158.
}

Khazanah, Vol. 19 (1), 2021 
melalui mengakomodir keberadaan kelompok-kelompok yang berbeda. Harapannya adalah untuk membuka pandangan kelompok-kelompok yang berbeda untuk memberikan penjelasan atas konsep tersebut.

Keempat, pendekatan aksi sosial. Pendekatan merupakan kombinasi antara pendekatan transformatif dengan pelaksanaan aktivitas terkait perubahan sosial. Pendekatan ini memiliki tujuan untuk memperkaya individu untuk secara aktif melakukan aksi sosial untuk menyelesaikan permasalahan terkait isu-isu sosial.

Toleransi merupakan sikap yang ditunjukkan oleh seseorang untuk memberikan kebebasan dalam menjalankan keyakinan dari setiap orang asalkan tidak melanggar prinsip-prinsip ketertiban dan keharmonisan dalam masyarakat. Perwujudan toleransi bisa berupa sikap dan perbuatan yang melarang tindakan diskriminatif atas prinsip-prinsip kelompok lain yang berbeda atau menerima perbedaan-perbedaan agar tetap terjalin harmonisasi dalam masyarakat. ${ }^{16}$

Toleransi menjadi salah satu sikap dasar sebuah karakter yang Islami oleh karena Islam merupakan ajaran agama yang mengajarkan tentang berkasih sayang dengan sesama. ${ }^{17}$ Lickona mengemukakan bahwa sebuah karakter akan terbentuk melalui tiga tahapan proses internalisasi yang saling berkaitan yaitu: moral knowledge, moral feeling dan moral action. ${ }^{18}$

Pada proses pendidikan sikap, khususnya bidang agama Islam sangat penting untuk mencakup ranah kognitif, afektif dan perilaku dari seseorang atau sebuah kelompok. Namun diantara ketiga aspek tersebut, pembinaan bagian afektif yang lebih rumit dalam penerapannya. ${ }^{19}$ Senada hal tersebut, Al Nahlawi menjelaskan bahwa pendidikan Islam adalah mengacu kepada Alquran dan sunah dalam ajarannya sehingga pada Alquran dan sunah pulalah terdapat berbagai metode pendidikan yang mampu menyentuh perasaan. Beberapa metode tersebut diantaranya Metode dialog, kisah Qurani dan Nabawi, perumpamaan, keteladanan, pembiasaan, Metode 'ibrah dan metode targhib. ${ }^{20}$

Mengacu pada penelitian-penelitian terdahulu terkait FKUB dalam mengembangkan kerukunan umat beragama melalui nilai-nilai Islam multikultural diantaranya adalah penelitian yang dilakukan oleh Rosyad. Hasil penelitian dilakukan di daerah Indramayu Jawa Barat memaparkan bahwa nilai multikultural yang penting untuk diberikan salah satunya adalah nilai toleransi. Pada proses aktualisasinya, nilai toleransi tersebut haruslah mengacu kepada spirit ajaran Islam yang mengacu pada Alquran dan Sunah yang bisa diberikan dalam bentuk pengajaran, pembinaan dan

\footnotetext{
${ }^{16}$ Masykuri Bakri and Dyah Werdiningsih, Membumikan Nilai Karakter Berbasis Pesantren: Belajar Dari Best Practice Pendidikan Karakter Pesantren Dan Kitab Kuning (Jakarta: Nirmana Media, 2017), 88.

${ }^{17}$ Hasan, Pendidikan Multikultural Sebagai Opsi Penanggulangan Radikalisme, 66.

${ }^{18}$ Thomas Lickona, Mendidik Untuk Membentuk Karakter: Bagaimana Sekolah Dapat Memberikan Sikap Pendidikan Hormat Dan Bertanggung Jawab (Jakarta: CV. Bumi Aksara, 2018), 70-89.

${ }^{19}$ Ahmad Tafsir, Ilmu Pendidikan Dalam Perspektif Islam (Bandung: PT. Remaja Rosdakarya, 2014), 135.

${ }^{20}$ Abdurrahman An Nahlawi, Pendidikan Islam Di Rumah, Sekolah Dan Masyarakat (Jakarta: Gema Insani Press, 2005), 204-5.
} 
keteladanan. ${ }^{21}$ Adapun penelitian yang dilakukan oleh Ikhwan tentang peran tokoh lintas agama dalam FKUB di Kota Malang memaparkan bahwa tokoh lintas agama yang tergabung dalam FKUB sangat berperan dalam memelihara kerukunan umat beragama. Mereka tidak ragu untuk turun langsung ke lapangan guna merawat keberagaman dan mengantisipasi konflik-konflik yang mungkin terjadi di masyarakat. ${ }^{22}$

Namun hasil penelitian Firdaus yang mengangkat tema terkait peran FKUB dalam mengembangkan kerukunan umat beragama menunjukkan hasil yang berbeda. Penelitian ini mengamati tiga kelompok besar wilayah kerja FKUB, yakni FKUB kelompok I (Kalimantan Tengah, Sumatera Utara, Bangka Belitung, NTT dan Sulawesi Tengah), kelompok II (DKI Jakarta, Kalimantan Barat, Jawa Barat dan Banten) dan kelompok III (Bengkulu, NAD dan Papua). Hasil penelitiannya menunjukkan bahwa tidak semua FKUB yang ada di masing-masing daerah berhasil dalam mengembangkan kerukunan umat beragama, khususnya FKUB yang berada pada wilayah kerja kelompok III. Banyak faktor yang menyebabkan hal tersebut terjadi salah satunya adalah miskomunikasi yang dilakukan oleh FKUB kepada masyarakat setempat. ${ }^{23}$

Mengacu pada penelitian-penelitian terdahulu tersebutlah yang membuat peneliti ingin menelaah lebih lanjut lagi terkait spirit toleransi yang digiatkan oleh FKUB. Peneliti mencoba untuk mendeskripsikan dan menganalisa spirit nilai toleransi dan implementasi pendidikan agama Islam multikultural dalam mengembangkan kerukunan umat beragama pada masyarakat Tengger yang dikembangkan oleh FKUB sebagai salah satu penggiat kerukunan umat beragama di masyarakat Tengger. Hal ini menjadi sangat penting mengingat ajaran Islam adalah ajaran yang damai yang mewajibkan setiap pemeluknya untuk mengakui dan memberikan kebebasan bagi agama lain agar sebuah komunitas masyarakat menjadi kesatuan sosial yang hidup berdampingan dalam damai.

\section{Metode}

Penelitian ini menggunakan pendekatan kualitatif dengan jenis studi kasus, yakni salah satu strategi dalam penelitian kualitatif guna meneliti kegiatan sebuah kelompok atau sistem dengan latar belakang tertentu secara mendalam. ${ }^{24}$ Metode pengumpulan data penelitian ini adalah observasi, wawancara dan dokumentasi. Observasi yang digunakan adalah observasi partisipatif yakni peneliti ikut terlibat

\footnotetext{
${ }^{21}$ Ali Miftakhu Rosyad, "Implementasi Nilai-Nilai Multikulturalisme Melalui Pembelajaran Pendidikan Agama Islam (The Implementation Of Multiculturalism Values Through Learning Of Islamic Religion Education)," Risâlah, Jurnal Pendidikan Dan Studi Islam 5, no. 1, March (2019): 16.

${ }^{22}$ M Ikhwan, "Tokoh Lintas Agama Merawat Kerukunan Umat (Belajar Multikultural Dari Kota Malang)," Palita: Journal of Social Religion Research 5, no. 2 (2020): 131.

${ }^{23}$ Muhammad Anang Firdaus, "Eksistensi FKUB Dalam Memelihara Kerukunan Umat Beragama Di Indonesia," Kontekstualita: Jurnal Penelitian Sosial Keagamaan 29, no. 1 (2014): 67.

${ }^{24}$ Muhammad Tholchah Hasan et al., Metode Penelitian Kualitatif (Surabaya: Visipress Media, 2013), 59.
} 
dalam kegiatan sehari-hari dari keadaan yang sedang diamati. Kegiatan wawancara yang dilakukan adalah kegiatan wawancara yang tidak terstruktur yakni peneliti melakukan proses tanya jawab hanya menggunakan garis besar topik saja, tidak secara spesifik dipersiapkan untuk ditanyakan kepada informan. Terkait dokumentasi, peneliti melakukan studi dokumen berdasarkan pada catatan-catatan jadwal kegiatan kunjungan FKUB, buku tamu, foto-foto kegiatan FKUB dan masyarakat Desa Krucil dan Desa Sukapura dan laporan-laporan hasil penelitian terdahulu yang relevan. ${ }^{25}$

Penelitian ini dilakukan pada masyarakat muslim di Desa Krucil Kecamatan Krucil dan Desa Sukapura Kecamatan Sukapura Kabupaten Probolinggo. Adapun informan pada penelitian ini dipilih dengan menggunakan cara purposive sampling, yaitu pemilihan informan dengan pertimbangan tertentu. ${ }^{26}$ Informan pada penelitian ini adalah ketua FKUB Kab. Probolinggo dan satu tokoh agama masyarakat Desa yang merupakan selaku penggiat toleransi di masyarakat Tengger. Untuk selanjutnya, data observasi, hasil wawancara dan studi dokumentasi akan dianalisis menggunakan model Miles dan Huberman, yakni menganalisa data melalui tahapan kegiatan kondensasi data, penyajian data dan dilanjutkan dengan penarikan kesimpulan. ${ }^{27}$

\section{Pembahasan}

\section{Nilai Toleransi dalam Pendidikan Agama Islam Multikultural pada Masyarakat Tengger}

Agama Islam merupakan agama yang mengajarkan tentang keharmonisan tanpa adanya kekerasan. Agama Islam mengajarkan tentang menghilangkan adanya kompetisi dengan agama lain, sehingga pemeluk agama Islam penting untuk memiliki sikap toleransi. Mengacu pada terminologi Alquran, misi mulai tersebut rahmatan lil 'alamin (rahmat bagi semesta alam).

Toleransi tidak akan bisa terwujud jika hanya dalam bentuk himbauan semata, melainkan harus melalui proses pendidikan untuk menanamkannya. Sebagaimana tertuang dalam UU No. 20 Tahun 2003 yang menyebutkan bahwa pendidikan nasional bertujuan untuk membentuk karakter, mengembangkan kemampuan dan memajukan peradaban bangsa agar bermartabat. Pada konteks pendidikan Islam yang tersistem, akan mampu menjadi solusi terbentuknya kepribadian yang berkualitas, ${ }^{28}$ yakni pribadi dengan karakter insan kamil melalui pola hidup sesuai dengan ajaran Allah Swt. ${ }^{29}$

Guna mewujudkan kehidupan masyarakat Indonesia yang sarat keberagaman pastilah bukan hal yang mudah, sehingga membutuhkan konsep-konsep pendidikan

\footnotetext{
${ }^{25}$ Sugiyono Sugiyono, Memahami Penelitian Kualitatif(Bandung: CV. Alfabeta, 2016), 62-82.

${ }^{26}$ Lexy J Moleong, Metodologi Penelitian Kualitatif (Bandung: PT. Remaja Rosdakarya, 2017), 224.

${ }^{27}$ Matthew B Miles, A Michael Huberman, and Johnny Saldana, Qualitative Data Analysis: A Methods Sourcebook Third Edition (USA: Sage Publications, 2014), 34.

${ }^{28}$ Triana Rosalina Noor, "Pendidikan Islam Sebagai Sebuah Sistem Di Era 4.0," TA'LIM: Jurnal Studi Pendidikan Islam 2, no. 2 (2019): 35, https://doi.org/10.29062/ta'lim.v2i2.1472.

${ }^{29}$ Zakiah Daradjat, Ilmu Pendidikan Islam (Jakarta: PT. Bumi Aksara, 2018), 29.
} 
khususnya konsep Pendidikan Agama Islam yang berwawasan multikultural. Melalui pendidikan multikultural, akan tersedia kesempatan bagi siapapun untuk bisa belajar tanpa membedakan gender, kelas sosial, etnis, ras dan karakteristik kultural. Bentuk pengembangan pendidikan multikultural pun akan disesuaikan karena di setiap daerah akan berbeda-beda sesuai dengan permasalahan yang dihadapi. ${ }^{30}$

Adapun nilai-nilai toleransi yang ada dalam kehidupan masyarakat Tengger, khususnya di Desa Krucil dan Desa Sukapura adalah :

1. Saling menghormati

Sikap saling menghormati yang dimaksud adalah masyarakat muslim Tengger memiliki sikap tidak melakukan persaingan dan banding membandingkan dengan capaian yang telah diraih masyarakat non-muslim. Masyarakat muslim Tengger memiliki sikap menerima setiap kemajuan dan keberhasilan oleh kelompok nonmuslim, salah satunya dalam hal ekonomi. Masyarakat Tengger menghormati baik itu usaha perekonomian, pekerjaan ataupun kehidupan sosial non-muslim yang pada beberapa hal lebih menonjol.

Masyarakat muslim di Desa Sukapura dan Desa Krucil memberi kesempatan bagi masyarakat non-muslim untuk membuka usaha, seperti membuka usaha rumah makan atau sama-sama bekerjasama menjadi pengaman kegiatan acara keagamaan seperti menjadi tukang parkir dan sebagainya. Masyarakat saling bekerjasama antara satu dengan lainnya agar bisa membawa keuntungan ekonomis bagi semua. ${ }^{31}$

Pendidikan Agama Islam Multikultural mengajarkan tentang saling menghormati semua orang tanpa diskriminatif. Sikap menghormati orang lain bukan berarti tidak menghargai jati diri sendiri dan mengorbankan kepentingan diri sendiri. Saling menghormati bisa dalam bentuk sikap menjaga agar tidak terjadi kekerasan melalui munculnya sikap berbagi diantara semua orang ataupun kelompok. ${ }^{32}$

\section{Kebebasan Beragama}

Kebebasan beragama yang dimaksud adalah masyarakat Tengger memberikan kebebasan dan kesempatan kepada masyarakat non-muslim untuk bisa beribadah sesuai agama dan kepercayaannya, asalkan tidak melanggar norma-norma sosial yang telah disepakati. Masyarakat muslim Tengger memberikan kesempatan kepada masyarakat non-muslim untuk melaksanakan ajaran agamanya sesuai dengan situasi dan kondisi masyarakat sekitar. Selain itu menghormati pula manakala ada kaum muslim yang memiliki keyakinan tertentu atas ibadah yang dilakukannya, sehingga tidak menganggap masyarakat muslim yang tidak melakukan ibadah sebagaimana dirinya sebagai bukan bagian masyarakatnya.

\footnotetext{
${ }^{30}$ Banks and McGee Banks, Multicultural Education: Issues And Perpectives 9th Edition, 156.

31"'Idrus, Wawancara, Probolinggo 29 Juli 2020."

${ }^{32}$ Zakiyuddin Baidhawy, Pendidikan Agama Berwawasan Multikultural (Jakarta: Erlangga, 2007), 83.
} 
Di Desa Sukapura dan Desa Krucil, warga saling melakukan silaturahmi antar masyarakat. Sikap masyarakat muslim Tengger memberi kebebasan kepada nonmuslim dalam beragama salah satunya ditunjukkan apabila Umat Hindu melakukan pawai ogo-ogo. Masyarakat muslim memberikan kesempatan umat Umat Hindu untuk merayakan, bahkan ada umat muslim yang ikut serta berpartisipasi sebagai pengaman kegiatan. $^{33}$

Pendidikan Agama Islam Multikultural mengajarkan keluhuran terkait menghargai perbedaan nilai-nilai yang berbeda dengan agama lain. Nilai pendidikan Islam untuk memberi kesempatan kepada orang lain untuk menjalankan haknya dalam menganut agama dan kepercayaannya melalui sikap empati dan simpati dalam keragaman agama. ${ }^{34}$

\section{Menerima Keberadaan Orang Lain}

Sikap menerima keberadaan orang lain yang ditunjukkan oleh masyarakat muslim Tengger adalah menerima sepenuh hati adanya keberagaman yang ada di masyarakat. Masyarakat menyadari tentang eksistensi keberadaan muslim berada di tengah keragaman budaya dan agama yang ada. Selain itu, masyarakat muslim Tengger dalam proses aktivitas sosial tetap mengikutsertakan keberadaan nonmuslim, seperti musyawarah terkait pengelolaan desa atau musyawarah dalam rangka penentuan keputusan kemajuan kepentingan bersama. Semua masyarakat dilibatkan dalam musyawarah, baik itu muslim ataupun non-muslim untuk bisa memberi masukan.

Masyarakat muslim dan non-muslim di Desa Krucil dan Desa Sukapura biasanya selalu melakukan musyawarah saat hendak menentukan sebuah keputusan. Tokoh masyarakat desa memberikan kesempatan kepada seluruh warga untuk memberikan ide dan gagasan seperti pada saat pembahasan program kerja desa, pembangunan infrastruktur desa dan kegiatan insidental lainnya. ${ }^{35}$

Mengakui keberadaan orang non-muslim dan sesama muslim dengan segala kelebihan dan kekurangannya membawa pada perilaku saling menghargai antara di masyarakat. Masyarakat muslim Tengger berusaha menerima sudut pandang pemikiran masyarakat non-muslim dengan sudut pandang mereka sendiri, karena jika menggunakan sudut pandang Islam pastilah akan muncul konflik dan gesekan.

\footnotetext{
33،"Idrus, Wawancara, Probolinggo 29 Juli 2020.”

${ }^{34}$ Kasinyo Harto, Model Pengembangan Pendidikan Agama Islam Berbasis Multikultural (Jakarta: PT. RajaGrafindo Persada, 2014), 72.

35"Idrus, Wawancara, Probolinggo 29 Juli 2020."
} 
Pendidikan Agama Islam Multikultural mengajarkan tentang bagaimana hidup berdampingan dalam kemajemukan agama dan budaya yang ada di masyarakat tanpa merasa terancam dengan keberadaan orang lain yang beda agama. ${ }^{36}$ Selain itu, menerima kehadiran orang lain dengan segala keberagaman dan ekspresi budaya yang dimiliki serta diposisikan sebagaimana mestinya, bukan dengan memaksakan untuk masuk dalam sebuah konsepsi agamanya sendiri. ${ }^{37}$

\section{Berpikir Positif}

Adapun bentuk berpikir positif yang dilakukan oleh masyarakat muslim Tengger adalah dengan membiasakan sikap baik sangka kepada orang lain. Semua anggota masyarakat dalam kehidupan sosial hidup saling menyayangi, menghormati dan tidak saling menyakiti. Semua lini masyarakat diberi kesempatan untuk memiliki kedudukan yang sama sehingga tidak muncul buruk sangka dalam lingkup sosial.

Masyarakat muslim Desa Krucil dan Desa Sukapura mengedepankan sikap baik sangka antar sesama anggota masyarakat. Masyarakat muslim tidak terjebak pada sikap ekstrim kiri maupun kanan. Pemikiran ini membawa dampak pada adanya kesadaran bahwa agama Islam adalah agama yang luwes, tidak sewenang-wenang dengan sesama manusia meskipun beda agama dan selalu menjaga keharmonisan lingkungan sekitar. ${ }^{38}$

Berpikir positif merupakan salah satu nilai luhur dari Pendidikan Agama Islam Multikultural agar dalam kehidupan tidak terdapat diskriminasi. Kehidupan sosial yang memberikan hak yang sama dari semua kalangan untuk mendapatkan apa yang sudah menjadi haknya. ${ }^{39}$ Harapannya adalah dengan segala pemenuhan hal terpenuhi sesuai porsinya, maka tidak muncul buruk sangka dan prasangka di dalam diri masing-masing anggota masyarakat.

\section{Implementasi Spirit Toleransi dalam Pendidikan Agama Islam Multikultural pada Masyarakat Tengger}

Pendidikan Agama Islam Multikultural telah mewarnai khazanah pendidikan Islam Indonesia yang sarat akan kebhinnekaan. Pendidikan Agama Islam Multikultural ini pada dasarnya adalah Pendidikan Agama Islam, hanya saja didasarkan kepada nilai-nilai pendidikan multikultural yang termuat dalam Alquran

\footnotetext{
${ }^{36}$ Mahmud Arif, "Pendidikan Agama Islam Inklusifmultikultural," Jurnal Pendidikan Islam 1, no. 1 (2011): 11.

${ }^{37}$ Naim and Sauqi, Pendidikan Multikultural: Konsep Dan Aplikasi, 52.

38“Idrus, Wawancara, Probolinggo 29 Juli 2020."

${ }^{39}$ Safi'i, Multikulturalisme Beragama Di Masyarakat (Kajian Pendidikan Islam, Hindu Dan Kristen), 68.
} 
dan Sunnah. Pendidikan Agama Islam Multikultural yang telah dikembangkan sesuai dengan nilai-nilai Islam sangat relevan untuk menjadi solusi pemecahan masalah di kehidupan masyarakat Indonesia yang multikultural. ${ }^{40}$ Nilai-nilai Islam multikultural yang salah satunya adalah nilai toleransi sangat tepat untuk menjawab permasalahan yang terjadi di masyarakat Tengger.

Implementasi Pendidikan Agama Islam Multikultural merupakan bentuk pelaksanaan dan perencanaan yang telah disusun dengan baik. Sebuah perencanaan pelaksanaan tersebut untuk akan dijadikan sebagai gambaran atas bentuk kegiatan konkrit yang akan dilaksanakan dalam mencapai tujuan. Implementasi Pendidikan Agama Islam Multikultural akan dikonstruksikan kepada kegiatan yang terintegrasi dengan sebuah kebiasaan ataupun budaya sebuah tempat. ${ }^{41}$

FKUB sebagai mitra pemerintah dalam menjaga kerukunan umat beragama terus berkoordinasi dengan masing-masing tokoh agama yang ada di masyarakat Tengger dan tidak terkecuali dengan tokoh agama Islam. FKUB berkoordinasi dengan para pemuka tokoh agama Islam merumuskan bentuk kegiatan yang akan dilakukan dalam rangka memperkuat kerukunan umat beragama melalui spirit toleransi yang digaungkan. ${ }^{42}$

Adapun spirit nilai toleransi yang hendak ditanamkan FKUB bersama tokoh agama Islam teruntuk kepada masyarakat Muslim Tengger Desa Sukapura dan Desa Krucil dilakukan dalam beberapa kegiatan sebagai berikut :

\section{Kegiatan tablil}

Tablilan merupakan kegiatan yang bisa dikatakan wajib bagi masyarakat muslim Desa Krucil dan Desa Sukapura. Tahlilan biasanya dilakukan tiap hari Kamis dan diikuti oleh seluruh anggota masyarakat yang tergabung sebagai jamaah tahlilan. Sebelum tahlilan dimulai biasanya ada wejangan-wejangan yang diberikan secara bergiliran oleh tokoh-tokoh agama. ${ }^{43}$

Kegiatan tablil merupakan salah satu kegiatan rutin yang dilaksanakan oleh masyarakat muslim Desa Sukapura dan Desa Krucil. Kegiatan tablil ini rutin dilakukan pada setiap hari Kamis malam selepas sholat Magrib. Kegiatan tablil dimaknai pula oleh masyarakat sebagai kirim doa bersama yang melibatkan anggota masyarakat yang baik itu yang berafiliasi dengan aliran Nahdlatul Ulama ataupun Muhammadiyah.

\footnotetext{
${ }^{40}$ M. Zainal Abidin, "Islam Dan Tradisi Lokal Dalam Perspektif Multikulturalisme," Millah: Jurnal Studi Agama 8, no. 2 (2009): 297-309.

${ }^{41}$ Mustafida, Pendidikan Islam Multikultural: Konsep Dan Implementasi Proses Pembelajaran PAI Berbasis Nilai-Nilai Multikultural, 59.

42،"Idrus, Wawancara, Probolinggo 29 Juli 2020."

43"Idrus, Wawancara, Probolinggo 29 Juli 2020."
} 
Tradisi tablil merupakan tradisi yang dilaksanakan secara turun temurun oleh warga Nahdliyin (masyarakat Nadlatul Ulama) dan juga masyarakat Indonesia secara umum. Tradisi ini dihormati kelangsungannya oleh warna non Nahdliyin untuk dilaksanakan dalam masyarakat.

Melalui kegiatan tablil ini, masyarakat ditanamkan tentang nilai-nilai toleransi bahwa tidak boleh berprasangka buruk terkait kebiasaan yang dilaksanakan oleh warga Nahdliyin. Selain itu melalui kegiatan tablilan ini pula mampu memunculkan semangat dakwah, membangun kebersamaan dan mendekatkan diri kepada Allah Swt.

\section{Kegiatan mauludan}

Kegiatan mauludan merupakan kegiatan rutin keagamaan Islam yang dilakukan oleh masyarakat Desa Sukapura dan Desa Krucil. Kegiatan mauludan ini dilakukan dalam rangka menjaga kelestarian budaya yang telah dilestarikan dari generasi ke generasi secara estafet. Kegiatan mauludan diikuti oleh semua anggota masyarakat muslim, dengan rasa kekeluargaan dan damai. Bagi masyarakat yang ikut serta ataupun tidak ikut serta pada hari kegiatan mauludan, saling membantu memberikan makanan, minuman untuk mensukseskan acara maulidan tersebut. Melalui kegiatan mauludan, masyarakat diingatkan terkait pentingnya sikap saling tolong menolong dan hidup rukun dalam kehidupan masyarakat.

Pada tradisi mauludan, biasanya masyarakat saling bantu antara satu dengan yang lain mulai dari makanan sampai dengan pada kegiatan pelaksanaan. Biasanya diceritakan kisah-kisah kehidupan Nabi Muhammad saw. yang relavan dengan kehidupan masyarakat Desa Krucil dan Desa Sukapura. Harapannya agar masyarakat bisa menjaga silaturahmi dan kebersamaan antar masyarakat. ${ }^{44}$

\section{Kegiatan pengajian umum}

Kegiatan pengajian umum biasanya dibuat dalam bentuk kegiatan ceramah kepada masyarakat muslim Desa Sukapura dan Desa Krucil. Melalui kegiatan pengajian umum ini, masyarakat bersama-sama hadir dalam pengajian tanpa membeda-bedakan siapa jamaah yang diperkenankan hadir. Melalui sering mendengar dan mengkaji ilmu agama diharapkan akan membentuk pribadi masyarakat yang berakhlak mulia.

Pada kegiatan pengajian umum, para tokoh agama memberikan pengajaran tentang nilai-nilai Pendidikan Agama Islam kepada para jamaah yang hadir. Jamaah

\footnotetext{
44“"Idrus, Wawancara, Probolinggo 29 Juli 2020.”
} 
biasanya diajarkan tentang nilai saling menghargai perbedaan, tidak boleh memaksakan kehendak dan tetap menjunjung tinggi semangat kekeluargaan. ${ }^{45}$

Melalui kegiatan pengajian umum, masyarakat bisa mendapatkan makna dari konsep pengajian umum bahwa antara orang yang satu dengan yang lain adalah bersaudara dan setara. Bersaudara dalam hal ukhuwah sesama muslim dan setara dalam hak mendapatkan kesempatan untuk mengikuti kajian. Nilai toleransi yang juga bisa diambil adalah jika terdapat perbedaan pendapat dari kajian dalam pengajian umum, maka tidak perlu memaksakan kehendak kepada orang lain.

\section{Kegiatan istighosah}

Kegiatan istighosah merupakan kegiatan keagamaan masyarakat muslim Tengger terkait permohonan bantuan kepada Allah. Istighosah sebagai bentuk permintaan pertolongan untuk dijauhkan dari segala bala bencana dan musibah yang melanda. Istighosah dilakukan dengan membacakan pujian-pujian dan doa berulangulang selesai sholat pada hari tertentu.

Istighosah ini biasanya dipimpin oleh tokoh agama yang sebelum pelaksanaan istighosah memberikan sambutan terkait manfaat dari kegiatan tersebut. Pelaksanaan istighosah ini mengharapkan datangnya keberkahan dalam lingkungan masyarakat, kehidupan bertetangga yang baik sehingga bisa hidup berdampingan dalam mendapatkan rezeki yang halal dan berkah untuk membiayai kehidupan keluarga. ${ }^{46}$

Pendidikan Agama Islam Multikultural nampak pada kegiatan istighosah ini. Saat istighosah ini dibacakan secara bersama-sama, maka terciptalah keakraban antara satu dengan yang lain. Kegiatan istighosah membawa makna bahwa melakukan sesuatu bersama-sama akan lebih dinamis. Terdapat keharmonisan antara pribadi satu dengan yang lain untuk tidak saling dahulu mendahului guna mendapatkan bacaan yang indah.

\section{Kegiatan suroan}

Kegiatan suroan adalah salah satu tradisi keagamaan yang masih dilestarikan sebagai peringatan bulan permulaan Hijriah. Pada bulan Muharam ini masyarakat melakukan tasyakuran dengan harapan akan mendapatkan rahmat dari Allah. Meskipun pelaksanaan kegiatan ini kental sekali unsur budaya dalam pelaksanaannya, namun hal tersebut tidak menyurutkan semangat untuk melestarikannya. Para masyarakat telah merasa memiliki budaya ini dan melestarikannya sebagai tradisi lokal sebagai identitas dan jati diri bangsa Indonesia.

\footnotetext{
45" Idrus, Wawancara, Probolinggo 29 Juli 2020."

"46“Idrus, Wawancara, Probolinggo 29 Juli 2020."
} 
Kegiatan suroan yang dilaksanakan oleh masyarakat mengajarkan bahwa pada bulan Muharam tersebut banyak peristiwa-peristiwa penting yang terjadi dalam Islam. Manfaatnya adalah masyarakat bisa menambahkan pengetahuan kepada generasi penerus terkait sejarah dan hakikat dari bulan Muharam itu sendiri.

Kegiatan suroan biasanya diisi oleh tokoh agama untuk menyampaikan tausiyahnya. Tokoh-tokoh agama ini mengemban misi sebagaimana FKUB untuk menjalani kehidupan dengan sabar, damai untuk kebahagiaan dunia dan akhirat. ${ }^{47}$

Berdasarkan telaah atas situasi dan kondisi yang terjadi pada masyarakat Tengger khususnya Desa Sukapura dan Desa Krucil, pendekatan yang diambil dalam proses implementasi Pendidikan Agama Islam Multikultural yang dilakukan melalui pendekatan aditif. Pendekatan aditif masih menjadi pilihan yang dilakukan oleh tokoh agama melalui koordinasi dengan FKUB. Pada pendekatan aditif, nilai-nilai Islam multikultural, yakni toleransi diberikan melalui menambahkan tema-tema atau sudut pandang mengenai multikulturalisme pada kegiatan keagamaan atau sosial kemasyarakatan.

Pada proses implementasi nilai toleransi yang dilakukan, harapannya adalah masyarakat Tengger bisa menjadi anggota masyarakat yang memiliki kualitas moral, kesantunan, rasa hormat, menghargai dan penerima perbedaan yang ada di masyarakat. Masyarakat mengetahui terkait konsep toleransi, konsep toleransi merasuk dalam perasaan dan diwujudkan dalam perilaku toleransi.

Jika mengutip Thomas Lickona, pendidikan tentang nilai erat hubungannya dengan pendidikan karakter. Tujuan pendidikan karakter adalah untuk mewujudkan perilaku sosial yang baik. Secara psikologis, pendidikan karakter harus mencakup dimensi pengetahuan berdasarkan pada moral (moral knowing), perasaan berdasarkan pada moral (moral feeling) dan perilaku berlandaskan pada moral (moral action). ${ }^{48} \mathrm{Jika}$ dikaitkan dengan nilai toleransi yang ditanamkan akan menjadi tolerance knowing, tolerance feeling dan tolerance action.

Mengacu pada pendapat Lickona fenomena yang terjadi di masyarakat Tengger bisa digambarkan bahwa FKUB bersama tokoh masyarakat Islam melakukan proses penanaman nilai toleransi dalam berbagai kegiatan. Penanaman pengetahuan tentang toleransi diberikan melalui pemberian pengetahuan nilai toleransi dalam sudut pendidikan Islam seperti melalui kegiatan pengajian umum. Setelahnya nilai toleransi itu akan ditanamkan "rasanya" di dalam masyarakat melalui kegiatan-kegiatan kemasyarakatan seperti mauludan dan lainnya. Dan pada tahap

\footnotetext{
47"“Idrus, Wawancara, Probolinggo 29 Juli 2020.” Wawancara.

${ }^{48}$ Muchlas Samani and Hariyanto Hariyanto, Konsep Dan Model Pendidikan Karakter (Bandung: PT. Remaja Rosdakarya, 2016), 50.
} 
aksinya, nilai toleransi tersebut terwujud bukan hanya dalam taraf mengetahui dan ingin melakukan, namun diimplementasikan dalam bentuk pembiasaan sehingga menjadi kebiasaan akan toleransi. Pembiasaan spirit toleransi sebenarnya adalah memasukkan pengalaman atas spirit toleransi tersebut sebagai bentuk akhir dari sebuah pengetahuan untuk mengembangkan kerukunan umat beragama. ${ }^{49}$ Pembiasaan dirasa cukup efektif sebagai metode dalam menanamkan nilai-nilai positif, ${ }^{50}$ termasuk nilai toleransi. Tujuan pembiasaan ini adalah terwujudnya kerukunan dalam masyarakat.

\section{Implikasi Spirit Toleransi dalam Pendidikan Agama Islam Multikultural Guna Mengembangkan Kerukunan Umat Beragama pada Masyarakat Tengger}

Saat membahas spirit toleransi dalam mengembangkan kerukunan umat beragama, maka tidak terlepas dari komponen nilai dan sikap. Komponen nilai tersebut terkait dengan nilai toleransi dan sikap akan berhubungan dengan sikap untuk menjaga dan mengembangkan kerukunan umat beragama.

Pada konteks masyarakat Tengger ini, nilai yang dimaksud adalah nilai agama yang mengajarkan toleransi, yakni nilai yang bersumber kepada dasar kebenaran dari Allah. Nilai agama yang dimiliki oleh seseorang diharapkan bisa mendorong seseorang untuk berpikir, berucap dan berperilaku toleran kepada orang lain sebagaimana ajaran Alquran dan Sunah.

Setelah nilai toleransi tersebut dipahami dalam konsep pemahaman dan "rasa" atas toleran tersebut maka selanjutnya adalah harus diwujudkan dalam sikap perilaku dalam keseharian. Sikap merupakan suatu bentuk evaluasi atau respon atas suatu perasaan. ${ }^{51}$ Sikap adalah suatu perilaku yang dilandaskan kepada sebuah nilai yang diyakini seseorang untuk mengarahkannya kepada hasil yang diinginkan dan yang tidak diinginkan. Dalam hal ini sikap menjaga kerukunan umat beragama dan mengembangkannya secara terus menerus adalah tujuan yang hendak dicapai.

Mengembangkan kerukunan umat beragama, melibatkan sikap anggota masyarakat untuk mewujudkannya melalui penanaman nilai dari Pendidikan Agama Islam Multikultural. Struktur sikap mengandung tiga komponen penting yang saling menopang, yakni komponen kognitif, komponen afektif dan komponen konatif. Komponen kognitif adalah bentuk gambaran atas apa yang diyakini oleh individu

\footnotetext{
${ }^{49}$ Tafsir, Ilmu Pendidikan Dalam Perspektif Islam, 144.

${ }^{50}$ Triana Rosalina Noor, "Upaya Guru Dalam Menanamkan Nilai Agama Di KB Al Muslim Surabaya," Edusiana: Jurnal Manajemen Dan Pendidikan Islam 4, no. 1 (2017): 75, https://doi.org/10.30957/edusiana.v4i1.7.

${ }^{51}$ Saifuddin Azwar, Sikap Manusia: Teori Dan Pengukurannya (Yogyakarta: Pustaka Pelajar, 2016), 5 .
} 
pemilik sikap, komponen afektif adalah komponen perasaan yang berkaitan dengan unsur emosional dan komponen konatif merupakan komponen perilaku yang dimiliki oleh seseorang. ${ }^{52}$

Komponen kognitif merepresentasikan bahwa untuk mengembangkan kerukunan umat beragama hendaklah warga masyarakat memiliki pemahaman yang terpola dulu terkait toleransi. Pemahaman toleransi akan membawa kepada asosiasi pemikiran positif yang diyakininya terkait pentingnya untuk saling menghormati, memberi kebebasan dan hidup berdampingan dalam masyarakat dengan harmonis. saat keyakinan akan nilai toleransi tersebut sudah menjadi dasar pengetahuan seseorang maka apapun tujuan dari sikap tersebut akan bisa diharapkan terwujud. Pengetahuan akan nilai toleransi yang berkombinasi dengan pengalaman akan kejadian yang dialami terkait nilai toleransi maka akan membawa kepada suatu kesiapan untuk melakukan pengalaman tersebut di masa datang saat berinteraksi dengan orang lain. Tujuan yang ingin diraih adalah tercapainya keteraturan dan keharmonisan dalam masyarakat.

Sebagai contoh, pandangan bahwa warga non-muslim yang tinggal di masyarakat Tengger adalah sesama manusia ciptaan Allah akan membawa kepada suatu keyakinan bahwa sesama makhluk ciptaan Allah haruslah menghormati, bukan malah dimusuhi. Keyakinan akan toleransi ini akan dikembangkan dan ditularkan kepada orang lain, pengalaman positif akan toleransi diceritakan kepada orang lain sehingga keyakinan itu tidak hanya berdasar stereotipe. Stereotipe merupakan suatu pemahaman kognisi yang didasarkan kepada pengalaman, namun pemahaman yang dimiliki cenderung salah sehingga pemahaman menjadi tidak akurat. ${ }^{53} \mathrm{Hal}$ ini dikarenakan manakala seseorang salah dalam meyakini suatu hal oleh karena pemahaman yang diyakini tersebut dasarnya salah secara norma maka pemahaman seseorang akan terganggu pada akhirnya. Akibatnya adalah terjadinya overgeneralisasi dan pembentukan stereotipe yang salah atas warga non-muslim.

Komponen kedua yang penting dalam mengembangkan kerukunan umat beragama adalah komponen afektif. Komponen afektif merupakan komponen yang melibatkan unsur emosi seseorang atas sebuah perilaku, dalam arti kata lain komponen afektif adalah perasaan seseorang atas suatu. Perasaan toleransi harus ditumbuhkan dalam diri warga. Perasaan ini berkaitan dengan keyakinan yang diyakini sebelumnya. Keyakinan negatif atas sesuatu hal akan membawa kepada reaksi emosional negatif pula atas hal tersebut. Emosi dan perasaan terganggu maka akan

\footnotetext{
${ }^{52}$ Azwar, 23-24.

${ }^{53}$ Salis Yuniardi, Psikologi Lintas Budaya (Malang: UMM Press, 2017), 27.
}

Kharanah, Vol. 19 (1), 2021 
terjadi perubahan perilaku sehingga hubungan interaksi sosial seseorang tersebut juga akan terganggu dan begitu pula sebaliknya. ${ }^{54}$

Jika dicontohkan dalam mengembangkan kerukunan umat beragama adalah seseorang yang memiliki keyakinan bahwa non-muslim itu adalah berbeda atau derajatnya lebih rendah dengan orang muslim, maka saat hidup berdampingan dengan warga non-muslim maka akan membawa kepada perasaan tidak suka atau benci. Kondisi tersebut pun berlaku sebaliknya, manakala memiliki keyakinan yang positif atas warga lain yang berbeda agama, maka tidak akan muncul perasaan ketidaksenangan untuk berbaur dan berinteraksi sosial dengan mereka.

Komponen ketiga adalah komponen konatif. Komponen konatif adalah komponen pembentuk sikap seseorang yang ditunjukkan melalui perilaku atau kecenderungan bertingkah laku atas nilai yang diyakininya. Pada konteks mengembangkan kerukunan umat beragama, aspek konatif ini adalah bentuk perilaku yang ditunjukkan untuk menjaga kerukunan umat beragama.

Sebagai contoh, saat seorang warga muslim Tengger memiliki keyakinan bahwa warga non-muslim itu semaunya sendiri untuk mendirikan rumah ibadah, maka perasaan yang dirasakan pastilah tidak nyaman dan ingin berontak dan pemikiran serta perasaan tersebut akan berimbas pada perilaku menghindari ketidaknyamanan tersebut dengan cara menolak berdirinya rumah ibadah.

Konsistensi keyakinan dan nilai sebagai komponen kognitif, komponen afektif dan komponen konatif maka terbentuklah sikap yang konsisten atas suatu hal. Adanya keyakinan atas nilai-nilai toleransi itu merupakan ajaran agama Islam yang diwujudkan dalam bentuk saling menghormati, saling menghargai, tidak berburuk sangka dan kebebasan dalam beragama akan membawa kepada suatu perasaan dan emosi positif yang dirasakan oleh seseorang saat harus berinteraksi dengan orang non-muslim. Melalui perasaan dan pemahaman nilai toleransi yang tepat maka akan ditunjukkan pada perilaku yang juga mendukung toleransi tersebut. Perilaku toleransi adalah perilaku yang bisa dilihat dan bisa dinilai karena perilaku dapat dimanifestasikan kepada perilaku yang terlihat langsung atau juga dalam bentuk pernyataan dan ucapan seseorang tersebut terkait toleransi.

Manusia adalah makhluk sosial yang selalu terkait pada sebuah interaksi sosial dengan orang lain. Cara pandang, cara berinteraksi, cara memersepsi dan bersosialisasi dengan orang lain sangatlah tergantung dari nilai yang dimiliki oleh seseorang. Agar cara pandang, cara berinteraksi dan memersepsi orang lain selaras dengan tujuan yang ditentukan maka perlu disiapkan lingkungan yang mendukung tujuan. Kerukunan umat beragama akan bisa tercapai manakala cara pandang, cara berinteraksi dan

${ }^{54}$ Bimo Walgito, Pengantar Psikologi Umum (Yogyakarta: CV. Andi Offset, 2010), 222. 
persepsi atas umat beragama sama-sama pada pemahaman atas nilai toleransi yang sama antara pribadi satu dengan yang lain. Selain itu lingkungan pun harus mendukung untuk hal tersebut. Lingkungan akan mempengaruhi perilaku seseorang dan perilaku seseorang pun akan mempengaruhi lingkungan. ${ }^{55}$

Dalam konteks mengembangkan kerukunan umat beragama di masyarakat Tengger khususnya Desa Sukapura dan Desa Krucil, maka FKUB bisa memposisikan sebagai mitra yang menyiapkan lingkungan yang toleran dan di dalam lingkungan tersebut terdiri dari anggota-anggota masyarakat siap berinteraksi untuk memiliki pemahaman, kesiapan emosi dan kekuatan perilaku untuk mewujudkan kerukunan umat beragama tersebut. Masyarakat Tengger bisa hidup berdampingan secara harmoni dan rukun dalam keberagaman oleh karena masing-masing pihak menjalankan fungsinya sebagai warga masyarakat yang menerapkan nilai-nilai multikultural. Bagi warga muslim, mereka menerapkan dengan baik nilai-nilai agama Islam multikultural yang salah satunya adalah toleransi. Pemahaman yang sama antara semua anggota masyarakat akan membawa pada keaktifan dari anggota masyarakat itu sendiri untuk terlibat aktif dalam menjaga dan mengembangkan kerukunan umat beragama.

\section{Simpulan}

Bangsa Indonesia sangat kaya akan kebhinnekaan yang manakala tidak bisa dikelola dengan baik akan memicu timbulnya konflik. Kerukunan umat beragama merupakan prioritas yang harus diperjuangkan dan dijaga oleh semua unsur masyarakat, salah satunya penanaman spirit toleransi melalui Pendidikan Agama Islam Multikultural.

Salah satu mitra penggiat spirit toleransi adalah FKUB Kabupaten Probolinggo, yang melakukan proses Pendidikan Agama Islam Multikultural kepada masyarakat muslim Tengger bersama tokoh masyarakat setempat. Nilai-nilai toleransi tersebut diberikan dengan harapan dalam kehidupan sosial kemasyarakatan akan bisa diterapkan saat berdampingan dengan orang lain meskipun berbeda agama. Adapun nilai-nilai toleransi yang telah berhasil diterapkan dalam masyarakat sosial Tengger adalah saling menghormati, kebebasan beragama, menerima keberadaan orang lain dan berpikir.

Pada proses implementasinya, proses penanaman spirit toleransi kepada masyarakat muslim dilakukan melalui kegiatan keagamaan seperti suroan, istighosah, pengajian umum, kegiatan mauludan dan kegiatan tahlil. Kegiatan ini prosesnya dilakukan oleh pemuka agama Islam sebagai mitra FKUB, yang berperan langsung

\footnotetext{
${ }^{55}$ Triana Rosalina Noor, "Analisis Desain Fasilitas Umum Bagi Penyandang Disabilitas (Sebuah Analisis Psikologi Lingkungan)," Journal An-Nafs: Kajian Penelitian Psikologi 2, no. 2 (2017): 134, https://doi.org/10.33367/psi.v2i2.438.
} 
dalam proses penanaman nilai pendidikan Islam multikultural tersebut. Nilai toleransi tersebut dilakukan dengan cara memberikan pemahaman dan pengetahuan terkait pentingnya spirit toleransi (tolerance knowing), untuk selanjutnya masyarakat muslim akan bisa merasakan "rasa" dari pentingnya toleransi dalam kehidupan masyarakat (tolerance feeling) dan pada akhirnya bisa hidup berdampingan dengan orang lain dalam masyarakat dan terciptalah kerukunan umat beragama (tolerance action).

\section{Daftar Pustaka}

Abidin, M. Zainal. "Islam Dan Tradisi Lokal Dalam Perspektif Multikulturalisme." Millab: Jurnal Studi Agama 8, no. 2 (2009): 297-309.

An Nahlawi, Abdurrahman. Pendidikan Islam Di Rumah, Sekolah Dan Masyarakat. Jakarta: Gema Insani Press, 2005.

Arif, Mahmud. "Pendidikan Agama Islam Inklusifmultikultural." Jurnal Pendidikan Islam 1, no. 1 (2011): 1-18.

Azwar, Saifuddin. Sikap Manusia: Teori Dan Pengukurannya. Yogyakarta: Pustaka Pelajar, 2016.

Baidhawy, Zakiyuddin. Pendidikan Agama Berwawasan Multikultural. Jakarta: Erlangga, 2007.

Bakri, Masykuri, and Dyah Werdiningsih. Membumikan Nilai Karakter Berbasis Pesantren: Belajar Dari Best Practice Pendidikan Karakter Pesantren Dan Kitab Kuning. Jakarta: Nirmana Media, 2017.

Banks, James A, and Cherry A McGee Banks. Multicultural Education: Issues And Perpectives 9th Edition. USA: John Wiley and Sons, Inc, 2016.

Daradjat, Zakiah. Ilmu Pendidikan Islam. Jakarta: PT. Bumi Aksara, 2018.

Firdaus, Muhammad Anang. "Eksistensi FKUB Dalam Memelihara Kerukunan Umat Beragama Di Indonesia." Kontekstualita: Jurnal Penelitian Sosial Keagamaan 29, no. 1 (2014): 58-71.

Harto, Kasinyo. Model Pengembangan Pendidikan Agama Islam Berbasis Multikultural. Jakarta: PT. RajaGrafindo Persada, 2014.

Hasan, Muhammad Tholchah. Pendidikan Multikultural Sebagai Opsi Penanggulangan Radikalisme. Malang: Lembaga Penerbitan Univ. Islam Malang, 2016.

Hasan, Muhammad Tholchah, Soetandyo Wignjosoebroto, Solichin Abdul Wahab, M Irfan Islami, Masykuri Bakri, and H B Sutopo. Metode Penelitian Kualitatif. Surabaya: Visipress Media, 2013.

Ikhwan, M. "Tokoh Lintas Agama Merawat Kerukunan Umat (Belajar Multikultural Dari Kota Malang)." Palita: Journal of Social Religion Research 5, no. 2 (2020): 113-34.

Institute, Setara. "Terjadi Penjalaran Intoleransi Di Daerah, Pemerintah Pusat Harus Hadir.” 29 September 2020, n.d. https://setara-institute.org/terjadipenjalaran-intoleransi-di-daerah-pemerintah-pusat-harus-hadir/. 
Lickona, Thomas. Mendidik Untuk Membentuk Karakter: Bagaimana Sekolah Dapat Memberikan Sikap Pendidikan Hormat Dan Bertanggung Jawab. Jakarta: CV. Bumi Aksara, 2018.

Miles, Matthew B, A Michael Huberman, and Johnny Saldana. Qualitative Data Analysis: A Methods Sourcebook Third Edition. USA: Sage Publications, 2014.

Moleong, Lexy J. Metodologi Penelitian Kualitatif. Bandung: P'T. Remaja Rosdakarya, 2017.

Munif, Achmad, and Ropingi Ropingi. "Peran Forum Kerukunan Umat Beragama (FKUB) Dalam Upaya Penangulangan Timbulnya Konflik Sosial Keagamaan Di Kota Kediri Tahun 2020.” Realita: Jurnal Penelitian Dan Kebudayaan Islam 19, no. 1 (2021): $\quad$ 84-95. https://doi.org/DOI: https://doi.org/10.30762/realita.v19i1.3272.

Mustafida, Fita. Pendidikan Islam Multikultural: Konsep Dan Implementasi Proses Pembelajaran PAI Berbasis Nilai-Nilai Multikultural. Jakarta: PT. RajaGrafindo Persada, 2020.

Naim, Ngainun, and Achmad Sauqi. Pendidikan Multikultural: Konsep Dan Aplikasi. Yogyakarta: Ar-Ruzz Media, 2017.

Niam, M Khusnun. "Peranan Majelis Taklim Áqo'idul Khomsin Pekalongan Terhadap Fenomena Takfirisme." Al-Adyan: Journal of Religious Studies 1, no. 1 (2020): 67-78.

Noor, Triana Rosalina. "Alternatif Pemecahan Masalah Pada Masyarakat Multikultural." Al Iman: Jurnal Keislaman Dan Kemasyarakatan 4, no. 2 (2020): 204-32.

. "Analisis Desain Fasilitas Umum Bagi Penyandang Disabilitas (Sebuah Analisis Psikologi Lingkungan)." Journal An-Nafs: Kajian Penelitian Psikologi 2, no. 2 (2017): 133-50. https://doi.org/10.33367/psi.v2i2.438.

. "Menepis Prasangka Dan Diskriminasi Dalam Perilaku Beragama Untuk Masa Depan Multikulturalisme Di Indonesia." Fikri: Jurnal Kajian Agama, Sosial Dan Budaya 5, no. 2 (2020): 210-22. https://doi.org/10.25217/jf.v5i2.1058.

. "Meneropong Indonesia: Sebuah Analisis Sosiologis Dan Psikologis Atas Konflik Benuansa Keagamaan Di Indonesia." Journal An-Nafs: Kajian Penelitian Psikologi 3, no. 2 (2018): 135-50. https://doi.org/10.33367/psi.v3i2.499.

. "Pendidikan Islam Sebagai Sebuah Sistem Di Era 4.0." TA'LIM: Jurnal Studi Pendidikan Islam 2, no. 2 (2019): 153-71. https://doi.org/10.29062/ta'lim.v2i2.1472.

. "Upaya Guru Dalam Menanamkan Nilai Agama Di KB Al Muslim Surabaya." Edusiana: Jurnal Manajemen Dan Pendidikan Islam 4, no. 1 (2017): 46-57. https://doi.org/10.30957/edusiana.v4i1.7.

Rosyad, Ali Miftakhu. "Implementasi Nilai-Nilai Multikulturalisme Melalui Pembelajaran Pendidikan Agama Islam (The Implementation Of 
Multiculturalism Values Through Learning Of Islamic Religion Education)." Risâlah, Jurnal Pendidikan Dan Studi Islam 5, no. 1, March (2019): 1-18.

Safi'i, Imam. Multikulturalisme Beragama Di Masyarakat (Kajian Pendidikan Islam, Hindu Dan Kristen). Malang: CV. Madza Media, 2020.

Samani, Muchlas, and Hariyanto Hariyanto. Konsep Dan Model Pendidikan Karakter. Bandung: PT. Remaja Rosdakarya, 2016.

"Sosialisasi Peraturan Bersama Menteri Agama Dan Menteri Dalam Negeri Nomor 9

Tahun 2006 Dan Nomor 8 Tahun 2006," n.d. https://www.kemendagri.go.id/.

Sugiyono, Sugiyono. Memahami Penelitian Kualitatif. Bandung: CV. Alfabeta, 2016.

Tafsir, Ahmad. Ilmu Pendidikan Dalam Perspektif Islam. Bandung: PT. Remaja Rosdakarya, 2014.

Tualeka, Hamzah. Sosiologi Agama. Surabaya: IAIN Sunan Ampel Press, 2011.

Walgito, Bimo. Pengantar Psikologi Umum. Yogyakarta: CV. Andi Offset, 2010.

Yuniardi, Salis. Psikologi Lintas Budaya. Malang: UMM Press, 2017. 